\title{
Statyba
}

\section{SOUND ABSORPTION CALCULATION IMPEDANCE METHOD FOR RESONATOR CEILING}

\section{Stauskis}

To cite this article: V. Stauskis (1996) SOUND ABSORPTION CALCULATION IMPEDANCE METHOD FOR RESONATOR CEILING, Statyba, 2:5, 92-100, DOI: 10.1080/13921525.1996.10531552

To link to this article: https://doi.org/10.1080/13921525.1996.10531552

曲 Published online: 26 Jul 2012.

Submit your article to this journal

山 Article views: 61

47 Citing articles: 1 View citing articles 지 


\section{IMPEDANSINIS REZONANSINIU KABAMŲJŲ LUBŲ GARSO ABSORBCIJOS SKAIČIAVIMO METODAS}

\section{Stauskis}

\section{Jvadas}

Ivairios paskirties salese, norint pasiekti optimaly reverberacijos laiką ir kitus akustinius rodiklius, skirtingose plokštumose reikia išdèstyti tam tikrą plotą garsą absorbuojančiu medžiagu. Šių medžiagų garso absorbcijos koeficientų dažninès charakteristikos turi būti skirtingos. Salèse dažniausiai reikia mažinti reverberacijos laiką esant žemiems dažniams tam, kad gautume optimalią reverberacijos laiko dažninę charakteristiką. Dèl to reikia naudoti akustines medžiagas, kurios gerai absorbuoja garsą esant žemiems dažniams. Tačiau praktikoje naudojamos akustinès medžiagos gerai absorbuoja garsą tik esant vidutiniams ir aukštiems dažniams. Tokiu atveju reikia naudoti specialias rezonansines garsą absorbuojančias konstrukcijas su gana dideliu oro tarpu tarp ju ir standaus paviršiaus. Tokios konstrukcijos dažnai neprïmtinos meniniu požiūriu, kuriant salès interjerą tai sudaro tam tikrų keblumų. Vienas šios problemos sprendimo būdas - ịrengti pakabinamas lubas iš ịvairaus pločio ir ilgio standžių plokštumų, tarp kuriụ bũtu palikti atitinkamo pločio ir skirtingos formos plyšiai. Tačiau reikia žinoti, kaip tokios konstrukcijos absorbuoja garsą esant ịvairiems dažniams ir kaip keičiasi objektyvūs salès akustiniai rodikliai. Šio darbo tikslas - sukurti rezonansiniu lubų su tarpais tarp plokštumu garso absorbcijos skaičiavimo metodą tuo atveju, kai plyšį plotis gali būti didesnis už garso bangos ilgi.

\section{Teorija}

Helmholco tipo rezonatoriy tyrimams daug démesio skyrè daugelio šaliu mokslininkai. U. Ingardas [1] nagrinejjo akustinių medžiagu su perforuotu ekranu garso absorbcines savybes, F.P. Mechelis [2] - plonu perforuotu metaliniu plokščị garso absorbcines savybes. P. Guignouard su kolegomis [3] tyrinéjo perforuoty plokščiu impedansą ir garso absorbcijos koeficientus. B. Brouardas su kolegomis [4] tyré garso absorbcijos koeficientus tarp pionų plokščiu, kuriose yra lygiagrečios mažo skersmens skylès. Šiuose darbuose skaičiuojama pagal klasikinị Helmholco rezonatorių. Pagal šią schemą garso bangos ilgis visada yra didesnis už skylès diametrą. Šiame rezonatoriuje buvo pateiktas analogiškas pavyzdys su elektros grandine, todèl laikoma, kad oro mase, judanti ertmeje, ir to oro stangrumas nepriklauso nuo dažnio. Todèl gaunamas vienas rezonansas. Be to, Helmholco rezonatoriaus skaičiavimas nèra visai tikslus, nes neịvertinama obertonų ịtaka.

Nagrinejamame akustiniame rezonatoriuje sužadinsime ne tik pagrindini rezonansą, bet ir obertonus, t.y. nelyginius harmonikus. Be to, ịvertinsime akustinio rezonatoriaus prijungtines oro mases skylés išorèje ir viduje, atskiru rezonatorị tarpusavio sąveiką ir plyšių piotị, kai šis yra didesnis už garso bangos ilgị.

Oro tarpus tarp lubų plokštumų nagrinèsime kaip skyles. Jụ apskaičiavimo schema pavaizduota 1 paveiksle.

Kabamujų lubų plokštumose plyšiu skaičius gali būti labai skirtingas ir tai priklauso nuo salés matmenų. Plyšiai gali būti arti vieni kitų, pvz., kai plyšio pločiai yra dideli, o plokštumų pločiai yra nedideli. Tai yra atvejis, kai garso bangos ilgis gali būti mažesnis už plyšio plotị. Plyšiai taip pat gali būti nutolę toli vieni nuo kitų, pvz., kai jụ pločiai yra maži, o plokštumų matmenys yra dideli. Šiuo atveju garso bangos ilgis gali būti 

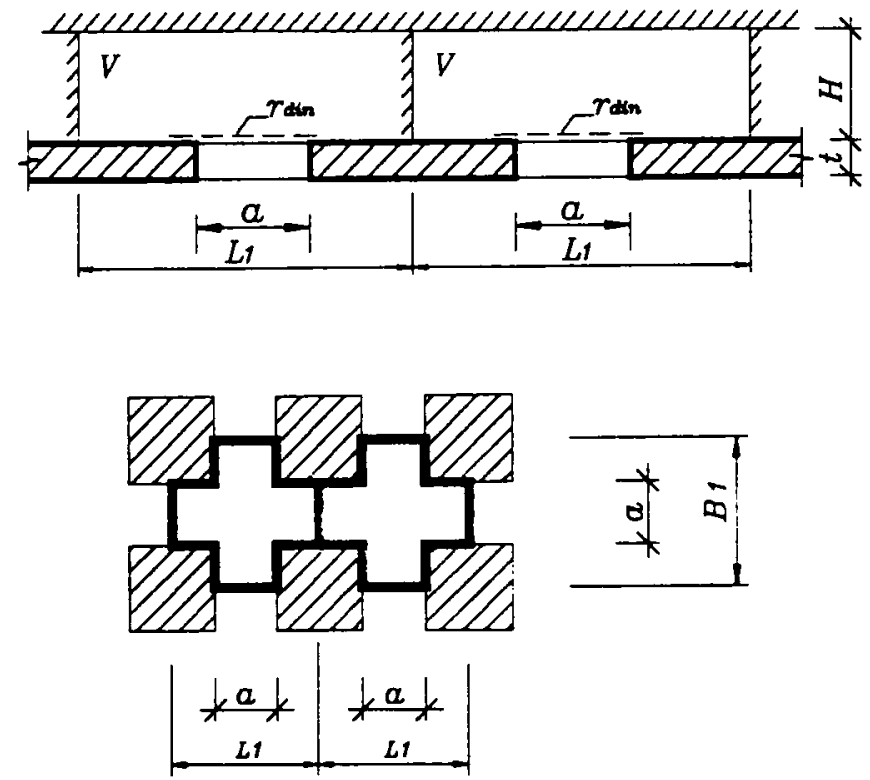

1 pav. Kabamuju rezonansiniu lubų schemos planas ir pjūvis

didesnis už plyšio plotị.

Jeigu plyšių yra daug ir jie yra arti vieni kitu, tai slègis tarp dvieju plyšiu ju plokštumoje ir pačioje skylejje keisis nesmarkiai, t.y. $P_{b}=P_{a}=\langle P\rangle$. Čia ženklai $<>$ reiškia vidurki ( $a$ - reiškia priklausomybę skylei, $b$ - visai plokštumai). Skylę traktuosime kaip rezonatorių, kurio matmenys yra nedideli palyginti su garso bangos ilgiu ir tada $\langle\mathrm{V} \cdot \mathrm{S}\rangle=\langle V\rangle S_{b}=V_{a} \cdot S_{a}$. Šiuo atveju plyšio impedansas yra lygus:

$$
Z=\frac{\langle P\rangle}{\langle V\rangle}=\frac{P_{a}}{V_{a} S_{a} / S_{b}}=Z_{m} \frac{1}{\varepsilon},
$$

kur $\varepsilon=S_{a} / S_{b}$ - ploto poringumo, perforacijos koeficientas; $Z_{m}$ - skylès impedansas.

Jeigu bangos ilgis yra mažesnis už maksimalu rezonatoriaus skylès matmeni, t.y. $\lambda<S_{a}$, tai kiekvienas rezonatorius garsa slopins atskirai. Garso energijos nuostoliai viename rezonatoriuje yra lygūs:

$$
W_{R}=\frac{1}{2}\left|V_{a}\right|^{2} R_{i} S_{a},
$$

kur $R_{i}$ - aktyvi rezonatoriaus vidaus nuostoliu varža.

Savo ruožtu oro dalelių svyravimo greitị galime išreikšti:

$$
\left|V_{a}\right|=\langle a\rangle \frac{\left|P_{e}\right|}{\left|Z_{m}\right|},
$$

čia $P_{e}$ - krintančios bangos slégis, o $\langle a\rangle$ - skaičius, gaunamas sumuojant krintančios ir atsispindejusios bangu slègius. Jeigu visa plokštuma, kurioje yra rezonatoriaus skyle, bus iš kietos medžiagos, tai $\langle a\rangle$ 2, t.y. bus beveik visas atspindys. Taigi, $\langle a\rangle$ gali keistis nuo 1 iki 2 .

Bendru atveju skyles impedansas $Z_{m}$ yra kompleksinis dydis, kurị sudaro pačios skylès impedansas ir oro tūrio tarp lubų ir plokščių impedansas.

Rezonatorius bus charakterizuojamas garso absorbcijos plotu, kuris lygus absorbuotos energijos santykiui su krintančios energijos santykiu, taigi

$$
P_{e}=\frac{1}{2} \frac{\left|P_{e}\right|^{2}}{Z_{0}}
$$

čia $Z_{0}=p_{0} c_{0}$ - oro impedansas.

Tada vieno rezonatoriaus efektyvus absorbcijos plotas išreiškiamas [5]

$$
A=\frac{W_{R}}{P_{e}}=\langle a\rangle^{2} \frac{R_{r} Z_{0}}{\left|Z_{m}\right|^{2}} S_{r},
$$

čia $Z_{m}$ - skyles impedansas, $S_{r}$ - rezonatoriaus plotas.

Taigi, noredami surasti rezonatoriaus absorbcija, turime surasti skylès impedansą. Jeigu tokiu rezonatoriu yra daug, tai norint gauti bendrą absorbciją, ju plotus reikia susumuoti, t.y. $A=A \cdot N$.

Krentančios garso bangos slègis $P_{i}$, susidūręs su skyle, ją veikia jèga $P_{i} S_{s k}$. Ši jèga dèl susidariusio 
slègio skyleje $P_{s}$ verčia svyruoti ten oro masę ir keičia oro suspaudimą $P_{v}$ skylès išorèje, t.y.:

$$
P_{e} S_{a}=P_{s} S_{a}+P_{a} S_{a}
$$

čia $P_{a}$ - slègis pačioje skylèje.

Žinant vidutinị oro greitị $\langle v\rangle$ visame skylès plote galime surasti impedansus:

$$
Z_{m}=Z_{m}^{\prime}+j Z_{m}^{\prime \prime}=\frac{P_{a}}{\langle v\rangle_{s}} \quad \text { ir } \quad Z_{s}=Z_{s}^{\prime}+j Z_{s}^{\prime \prime}=\frac{P_{s}}{\langle v\rangle_{s}} .
$$

Bendras impedansas bus šį abiejų impedansų suma:

$$
Z_{R}=Z_{m}+Z_{s}
$$

ir bendru atveju galime parašyti:

$$
Z_{R}=R_{i}+R_{2}^{\prime}+j Z_{R}^{\prime \prime},
$$

čia $R_{i}$ - vidiniai nuostoliai, $R_{2}^{\prime}$ - spinduliavimo varža, $Z_{R}^{\prime \prime}$ - reaktyvinè impedanso dalis, kuri susideda iš svyruojancios efektyvios masés $m_{e f}$, ta mase uždaryto oro stangrumo $\sigma_{e f}$ ir išreiškiama

$$
j Z_{R}^{\prime \prime}=\frac{j \omega m_{e f}}{S_{a}}+\frac{\sigma_{e f}}{j \omega S_{a}} .
$$

Pirmiausia surasime patị skyles impedansą. Jis susideda iš keturiụ daliu (2 paveikslas):

$$
Z_{m}=Z_{m 0}+Z_{m a}+Z_{m i}+Z_{v},
$$

čia $Z_{m 0}$ - pačios skylès impedansas; $Z_{m a}$ - prijungtos oro masès impedansas skylès išorèje; $Z_{m i}$-prijungtos oro masés impedansas skylès viduje, $Z_{v}$ - rezonatoriaus tūrio impedansas.

Skylèje svyruojantis oro kamštis gali būti laikomas stūmokliniu, kai oro daleliụ svyravimo greitis visame plote yra vienodas. Tada pačios skylès impedansas išreiškiamas

$$
Z_{m 0}=j \omega \rho_{e f}
$$

čia Pef $t$ - reiškia svyruojančią efektyvią masę skylès viduje, $t$ - skylès storis.

Prijungtos oro masés impedansas skyles viduje yra lygus:

$$
Z_{m i}=j \omega \rho_{e f} \cdot \Delta t_{i}
$$

čia $\Delta t_{i}$ - prijungtinè oro masè skylès viduje.

Prijungtos oro masès impedansas skylès išoreje yra lygus:

$$
Z_{m a}=Z_{r}+j \omega \rho_{e f}^{\prime} \cdot \Delta t_{a} .
$$

čia $\Delta t_{a}$ - prijungtinè oro masè skylès išorèje, $Z_{r}$ - skylès spinduliavimo impedansas.

Oro tekejjimo per cilindrines skyles rezultatus galima pritaikyti bet kurio tipo skylems pakankamai tiksliai.

Helmholco priartèjimas oro pratekéjimui pro cilindrines skyles aprašomas formulèje [6]:

$$
\rho_{e f}=p_{0}\left(1+2 \frac{\sqrt{-j}}{\mu}\right) \text {, }
$$

o tai reiškia, kad banga turbulentiškai teka skylès kraštais.

Čia $\mu=a \sqrt{\omega \rho_{0} / \eta}, \eta$ - oro klampumas. Išskaidžius ị realiają ir menamają dalị turessime:

$$
\rho_{e f}=\rho_{0}\left(1+\frac{1}{a} \sqrt{\frac{8 \eta}{\omega}}\right)-j \frac{\rho_{0}}{2 a} \sqrt{\frac{8 \eta}{\omega \rho_{0}}} .
$$




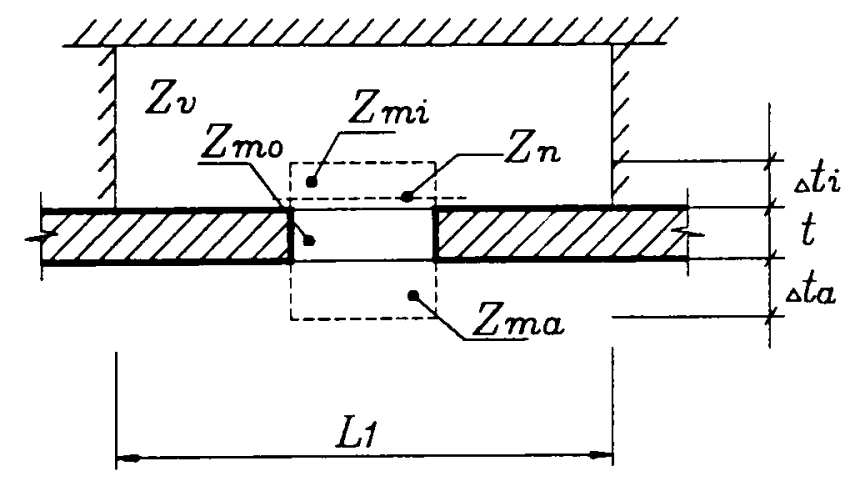

2 pav. Akustinio rezonatoriaus skyles ir prijungtu oro masiu impedansų išsidèstymo schema

Čia $2 a$ żymi skylès diametrą, kurị vèliau pakeisime skylès - perimetru. İstatę (16) i (12) gauname pačios skylés impedansą

$$
Z_{m 0}=\frac{\rho_{0} t}{2 a} \sqrt{\frac{8 \eta}{\rho_{0}}} \cdot \omega+j \omega \rho_{0} t\left(1+\frac{1}{2 a} \sqrt{\frac{8 \eta}{\omega \rho_{0}}}\right)
$$

Šio impedanso reali dalis nusako trinties nuostolius, kurie atsiranda orui judant skyle. Tokie pat nuostoliai turi būti ir orui judant abipus skylès. Tada prijungtinès oro masès impedansas skylès išorèje yra lygus:

$$
Z_{m a}=Z_{r}+\frac{\rho_{0} \Delta t_{a}}{2 a} \sqrt{\frac{8 \eta}{\rho_{0}}} \cdot \omega+j \omega \rho_{0} \frac{\Delta t_{a}}{2 a} \sqrt{\frac{8 \eta}{\omega \rho_{0}}} .
$$

čia $Z_{r}$ - spinduliavimo impedansas, kuris yra lygus

$$
Z_{r}=\rho_{0} c_{0}\left(k_{0} a_{e f}\right)^{2}+j \omega \rho_{0} \Delta t
$$

Prijungtas oro masés impedansas skylès viduje skaičiuojamas pagal formulę:

$$
Z_{m l}=\frac{\rho_{0} \Delta t_{i}}{2 a} \sqrt{\frac{8 \eta}{\rho_{0}}} \omega+j \omega \rho_{0} \frac{\Delta t_{i}}{2 a} \sqrt{\frac{8 \eta}{\omega \rho_{0}}}
$$

ir $\frac{\pi}{4 a} \leq t \leq \frac{8}{3 \pi} a$.

Pataisa $8 a / 3 \pi$ atsiranda iš oro kamščio reaktyvios spinduliavimo varžos, o reali spinduliavimo varža nusakoma pirmuoju $Z_{r}$ nariu. Ši reali dalis prijungiama prie impedanso tik iš laisvosios plokštumos pusés, nes garsas spinduliuojamas tik iz tą pusę.

Lubų ịtaka impedansui skyliụ plokštumoje nustatoma transformuojant lubų impedansą ị tą plokštumą. Transformavimą aprašo lygtis

$$
Z_{v}=Z_{0} \frac{Z_{1} \operatorname{coth} k_{0} H+Z_{0}}{Z_{1}+Z_{0} \operatorname{coth} k_{0} H}
$$

čia $k_{0}$ - bangu skaičius tarp plokštumos ir lubu;; $H$ - atstumas nuo plokštumos iki lubų; $Z_{1}$ - lubų impedansas.

Jeigu lubos charakterizuojamos slopimo koeficientu $\alpha$, tai

$$
Z_{1}=Z_{0} \frac{1+x}{1-x}
$$

čia $x=\sqrt{1-\alpha}$ - yra atspindžio koeficientas.

Ivesti $\alpha$ būtina, nes netgi betono, tinko ar panašių medžiagu lubos nevisiškai atspindi patekusị i jas garsą. 
Galima pakeisti cilindrinès skylès konfigūraciją pakeitus formulę:

$$
\frac{1}{2 a} \frac{2 \pi a}{2 \pi a}=\frac{2 \pi a}{4 \pi a^{2}}=\frac{u}{4 S_{a}},
$$

čia $u$-skyles perimetras; $S_{a}$ - skyles plotas. Be to, pataisa $\Delta t^{\prime}=\frac{2 a \pi}{\pi}=\frac{u}{\pi}$, o $\Delta t=\frac{8 a}{3 \pi}$ ir priklauso nuo plyšio formos.

Taigi, galutinis impedansas yra lygus:

$$
Z_{m}=\frac{u(t+u / \pi)}{4 S_{r}} \rho_{0} \sqrt{\frac{8 \eta \omega}{\rho_{0}}}+\rho_{0} c_{0}\left(k_{0} e_{e f}\right)+j \omega \rho_{0}\left[1+2 \Delta t+\frac{u / t+u / \pi}{4 S_{r}} \sqrt{\frac{8 \eta}{\omega \rho_{0}}}\right]+Z_{\nu},
$$

čia $\quad k_{0} e_{e f}=\frac{\pi}{2} k_{0} a-$ ilgam plyšiui, kurio plotis $a$;

$2 \Delta t=a \frac{\pi}{8}\left(1-\frac{a}{b}\right)$ - ilgiems plyšiams, išdèstytiems su tarpais $b$.

Tada galutinis impedansas ilgam a pločio plyšiui yra lygus:

$$
Z_{m}=\frac{u(t+u / \pi)}{4 S_{r}} \rho_{0} \sqrt{\frac{8 \eta}{\rho_{0}} \omega}+\rho_{0} c_{0}\left(\frac{\pi}{2} k_{0} a_{e f}\right)+j \omega \rho_{0}\left[1+2 \Delta t+\frac{u / t+u / \pi}{4 S_{r}} \sqrt{\frac{8 \eta}{\omega \rho_{0}}}\right]+Z_{\nu} .
$$

Ilgiems plyšiams, išdèstytiems su tarpais $L_{1}$, impedansas lygus:

$$
Z_{m}=\frac{u(t+u / \pi)}{4 S_{r}} \rho_{0} \sqrt{\frac{8 \eta}{\rho_{0}}} \omega+\rho_{0} c_{0}\left(k_{0} a_{e f}\right)+j \omega \rho_{0}\left[1+a \frac{\pi}{8}\left(1-\frac{a}{L_{1}}\right)+\frac{u / t+u / \pi}{4 S_{r}} \sqrt{\frac{8 \eta}{\rho_{0}}} \omega\right]+Z_{v}
$$

Bendras impedansas, išdèstytas skyliu plokštumoje bus

$$
Z=Z_{m}+Z_{v}
$$

Dydis $\rho_{0} c_{0}\left(k_{0} e_{e f}\right)$ yra reali spinduliavimo impedanso dalis, kuri labai priklauso nuo plyšio geometrines formos. Nuo jos taip pat priklauso ir pataisa $2 \Delta t$.

Jeigu garso banga i plokštumą krenta ne normaliniu kampu, o kampu $\theta$, tai suradus impedansą, randamas atspindžio koeficientas

$$
x=\frac{Z_{0}-Z_{m} \cos \theta}{Z_{0}+Z_{m} \cos \theta}
$$

ir bendras absorbcijos koeficientas $\alpha=1-|x|$, kuris priklauso nuo $\theta$.

Difuziniam laukui apskaičiuoti reikia išvesti vidurkị visais kritimo kampu atvejais, o tai reiškia suintegruoti visus kritimo kampus nuo $0^{\circ}$ iki $90^{\circ}$. Tokiu būdu gaunama galutinè lubu garso absorbcijos koeficiento reikšmé. Absorbcija, absorbcijos koeficientas ir reverberacijos laikas kompiuteriu buvo apskaičiouti tam tikrai salei, keičiant lubụ geometrinius parametrus.

\section{Skaičiavimo rezultatai}

Naudojant saleje kabamąsias lubas, būtina žinoti, kokią ịtaką šios lubos turès salès reverberacijos laikui. Tam būtina apskaičiuoti visos salès garso absorbcijos koeficientų ir bendrosios salès absorbcijos dažninẹ priklausomybę. Skaičiavimams pasirinkta statoma Lietuvos radijo ir televizijos simfoninio orkestro irašu studija, kurios akustini projektạ paruošé šio darbo autorius. Šios studijos ilgis $34 \mathrm{~m}$, plotis $22 \mathrm{~m}$ ir aukštis $12 \mathrm{~m}$. Skaičiuojant laikème, kad atstumai tarp plokšciu, t.y. plyšio plotis, yra $100 \mathrm{~cm}$. Jis liko toks pat, o keitėsi tik atstumas iki standaus lubų paviršiaus, kuris yra 5, 20, 35, 60, 75 ir $80 \mathrm{~cm}$ Kabamuju lubų planas pavaizduotas 3 paveiksle.

Kabamuju lubų su kryžiaus formos plyšiais tarp plokštumu garso absorbcijos koeficientai ir bendroji lubụ 


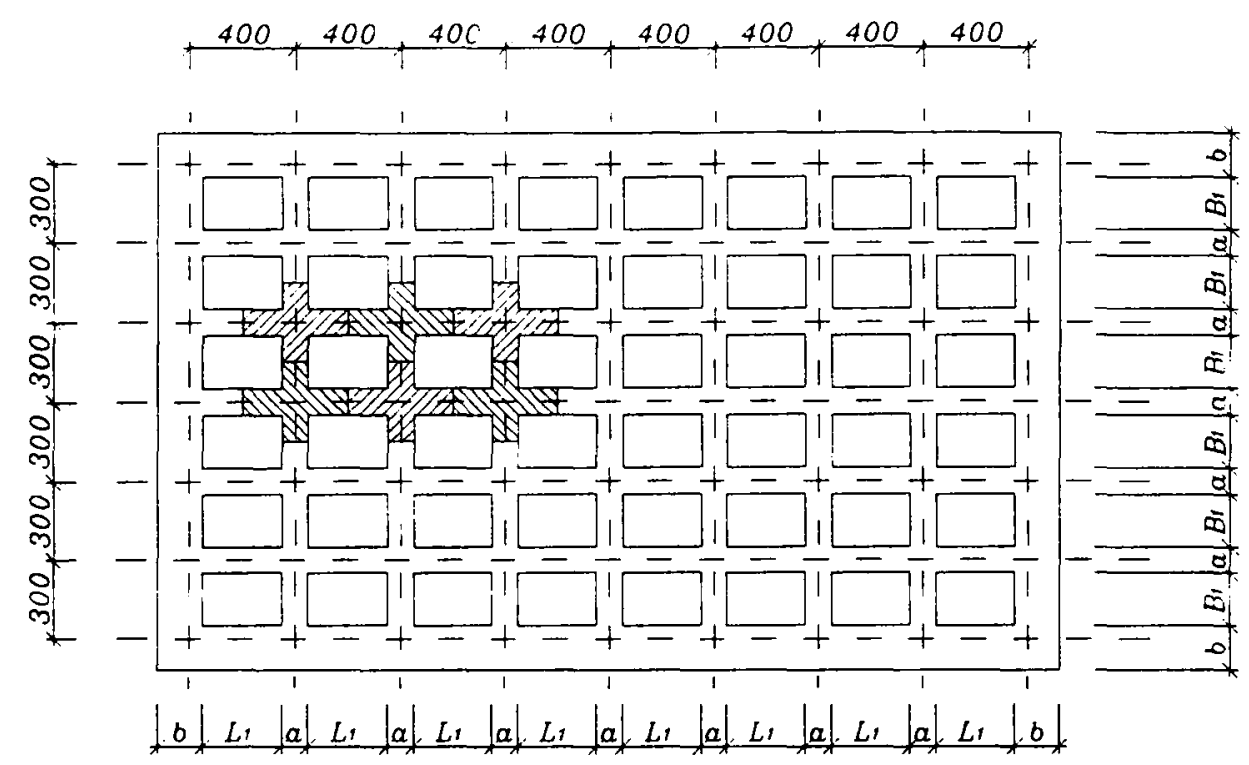

3 pav. Kabamuju lubų su kryžiaus formos plyšiais tarp plokštumy išdèstymo schema

absorbcija, skirtingai nuo reverberacijos laiko dažninès charakteristikos, buvo apskaičiuoti neįvertinus visos sales paviršiaus akustiniu savybių Standaus lubų paviršiaus ir kabamujų lubų plokštumų absorbcijos koeficientai buvo lygūs 0 , sienų absorbcijos koeficientai - nuo 0,02 iki 0,04 , grindų - nuo 0,04 ik 0,07 . Skaičiuota su salyga, kad saleje yra 100 atlikèju, o ju absorbcijos koeficientai - nuo 0,3 iki 0,7 . Taip pat ịvertinta garso absorbcija ore, kuri yra nemaža esant aukštiems dažniams o esant $4000 \mathrm{~Hz}$, siekia $200 \mathrm{~m}^{2}$. Papildomos garso absorbcijos koeficientai buvo nuo 0,07 esant žemiems dažniams iki 0,03 esant aukštiems. Esant bendram paviršiaus plotui $2910 \mathrm{~m}^{2}$ papildoma absorbcija keitesi nuo $204 \mathrm{~m}^{2}$ esant $125 \mathrm{~Hz}$ iki $88 \mathrm{~m}^{2}$ esant $4000 \mathrm{~Hz}$. Tokiu būdu bendra visos salès paviršiaus absorbcija keitèsi nuo $282 \mathrm{~m}^{2}$ esant žemiems dažniams iki $446 \mathrm{~m}^{2}$ esant aukštiems. Vidutinis viš salès paviršį absorbcijos koeficientas nuo $100 \mathrm{iki} 2000 \mathrm{~Hz}$ yra lygus $0,09-0,11$, o esant $4000 \mathrm{~Hz}-0,15$. Tokios didelès sales, kurios tūris yra beveik $9000 \mathrm{~m}^{3}$, absorbcijos koeficientai yra per maži. Todél salés reverberacijos laikas be kabamujụ lubų gaunamas labai didelis - apie $5 \mathrm{~s}$ esant žemiems dažniams ir 3,3-4,8 s esant vidutiniams ir aukštiems. Toks pasirinkimas leis geriausiai nustatyti ịvairių plyšiu pločių tarp kabamujų lubu plokštumų ịtaką salès akustiniams rodikliams. Minèti sales absorbcijos koeficientai ir bendroji sales absorbcija buvo ịvertinti tik apskaičiavus salès reverberacijos laiko dažninę charakteristiką.

4 paveiksle pavaizduota, kaip kinta kabamuju lubų bendroji garso absorbcija kintant plokštumos atstumui iki standaus lubu paviršiaus.

Matome, kad pakabinamos lubos su plyšiais tarp plokštumy absorbuoja labai daug garso energijos. Absorbcija turi labai ryškų rezonansinị charakterị. Kai lubų atstumas iki standaus paviršiaus yra tik $5 \mathrm{~cm}$, tai absorbcijos esant žemiems dažniams visai nera. Ji pasireiškia esant tik aukštiems dažniams ir yra apie $300 \mathrm{~m}^{2}$. Šiuo atveju nèra išreikšto rezonanso. Padetis keičiasi didejant atstumui iki standaus paviršiaus. Kai $H=20 \mathrm{~cm}$, tai absorbcija turi ryškų rezonansinị charakterị ir jos maksimumas esant $315 \mathrm{~Hz}$ siekia apie $700 \mathrm{~m}^{2}$. Esant žemiems ir aukštiems dažniams absorbcija staigiai mažèja. Didejant lubų atstumui iki standaus paviršiaus rezonansinis dažnis pasistumia žemų dažnių diapazono link ir rezonansinès kreives plotis nuolat dideja. Tai aiškiai matyti lyginant 2 ir 6 kreives, kuriu minétas atstumas yra 20 ir $80 \mathrm{~cm}$. Esant $65 \mathrm{~cm}$ atstumui maksimali absorbcija, kuri yra apie $700 \mathrm{~m}^{2}$, užima $80-160 \mathrm{~Hz}$ dažnių intervalą. Kai šis atstumas pakinta visai nedaug - iki $80 \mathrm{~cm}$, tai maksimali absorbcija išlieka tokia pati - apie $700 \mathrm{~m}^{2}$, bet jos dažnių diapazonas prasiplečia nuo 63 iki $200 \mathrm{~Hz}$.

Garso absorbcija labai priklauso nuo garso bangos kritimo kampo. 5 paveiksle pavaizduota, kaip kinta lubu garso absorbcijos plotas, keičiantis bangos kritimo kampui. 


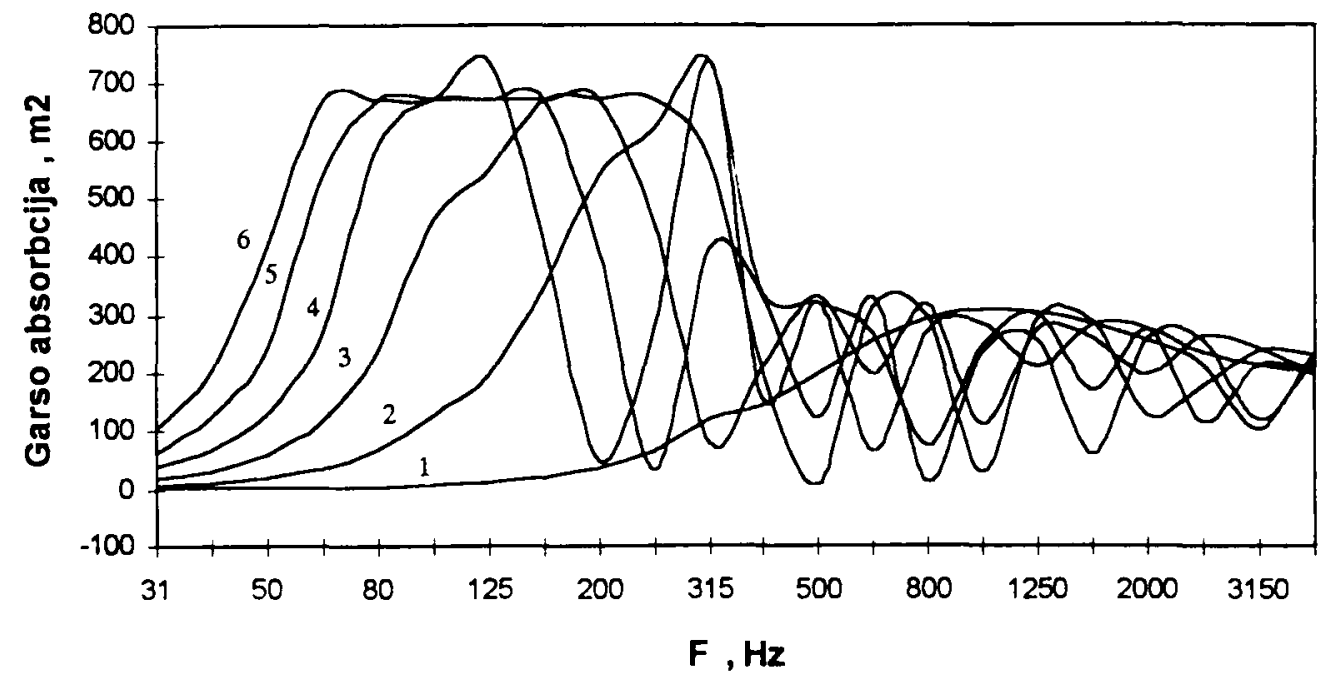

4 pav. Kabamuju luby su kryžiaus formos plyšiais tarp plokštumy garso absorbcijos priklausomybe் nuo atstumo tarp plokšrumos ir standaus lubu paviršiaus. Plyšio plotis $100 \mathrm{~cm} .1,2,3,4,5$ ir 6 atstumas iki standaus paviršiaus atitinkamai $5,20,35,50,65$ ir $80 \mathrm{~cm}$

Iš grafiko matyti, kad esant nedideliam $5^{\circ}$ ir $20^{\circ}$ bangos kritimo kampui ( 1 ir 2 kreivés), maksimali absorbcija esant $200 \mathrm{~Hz}$ yra $400 \mathrm{~m}^{2}$. Didèjant šiam kampui, rezonansas pasistumia aukštu dažniu link, o absorbcijos plotas nesikeičia. Didžiausia absorbcija yra tada, kai bangos kritimo kampas yra $80^{\circ}$, t.y., kai banga beveik šliaužia plokštès paviršiumi. Šiuo atveju rezonansas vyksta esant $2200 \mathrm{~Hz}$ ir maksimali lubu absorbcija yra net apie $700 \mathrm{~m}^{2}$.

Konstrukcijos garsą absorbuojančias savybes visada geriau charakterizuoja jos garso absorbcijos koeficientas. Jis paprastai gaunamas dalijant bendrają absorbciją iš paviršiaus ploto. 6 paveiksle pavaizduota, kaip kinta garso absorbcijos koeficientas kintant lubu atstumui iki standaus paviršiaus.

Absorbcijos koeficiento kitimo charakteris yra toks pat, kaip ir garso absorbcijos. Maksimali jo reikšme yra apie 0,9 ir yra labai didelè. Maksimalus garso absorbcijos koeficientas yra tada, kai lubų atstumas iki standaus paviršiaus yra $80 \mathrm{~cm}$.

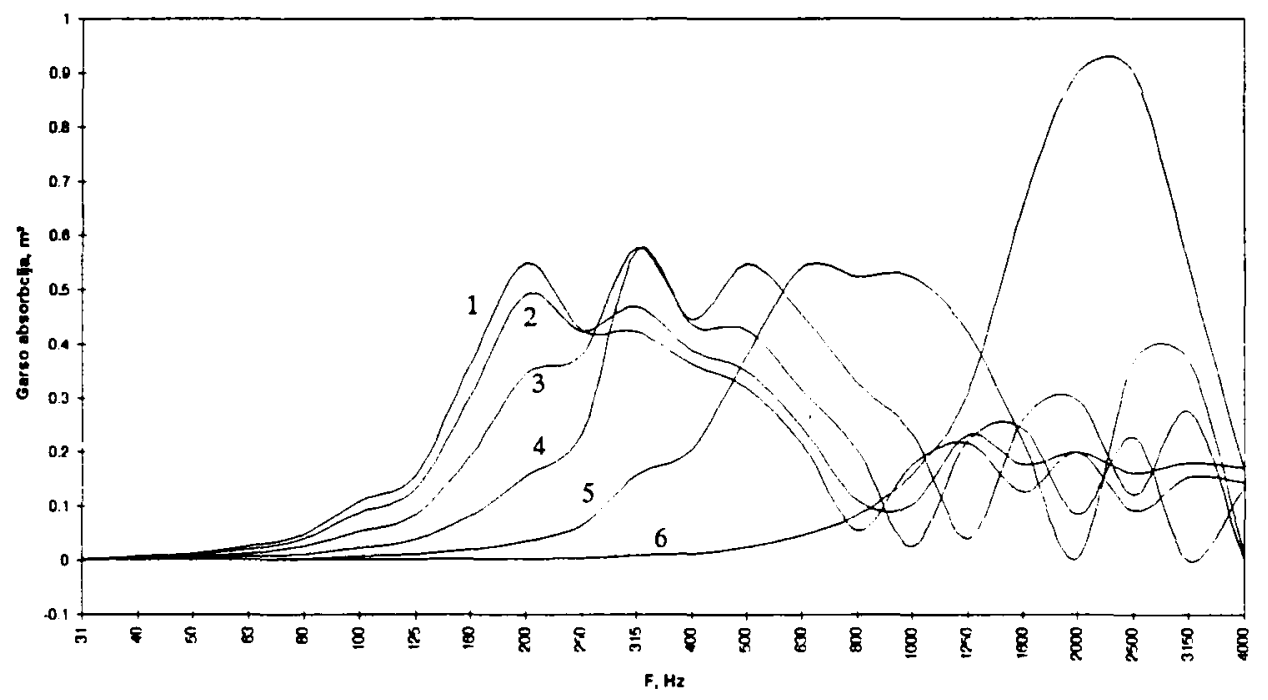

5 pav. Kabamuju luby su kryžiaus formos plyšiais tarp plokštumy garso absorbcijos priklausomybe nuo bangos kritimo kampo. Plyšio plotis - $50 \mathrm{~cm}$, atstumas iki standaus luby paviršiaus $-20 \mathrm{~cm} .1,2,3,4$, 5 ir 6 bangos kritimo kampas atitinkamai $5^{\circ}, 20^{\circ}, 35^{\circ}, 50^{\circ}, 65^{\circ}$ ir $80^{\circ}$ 


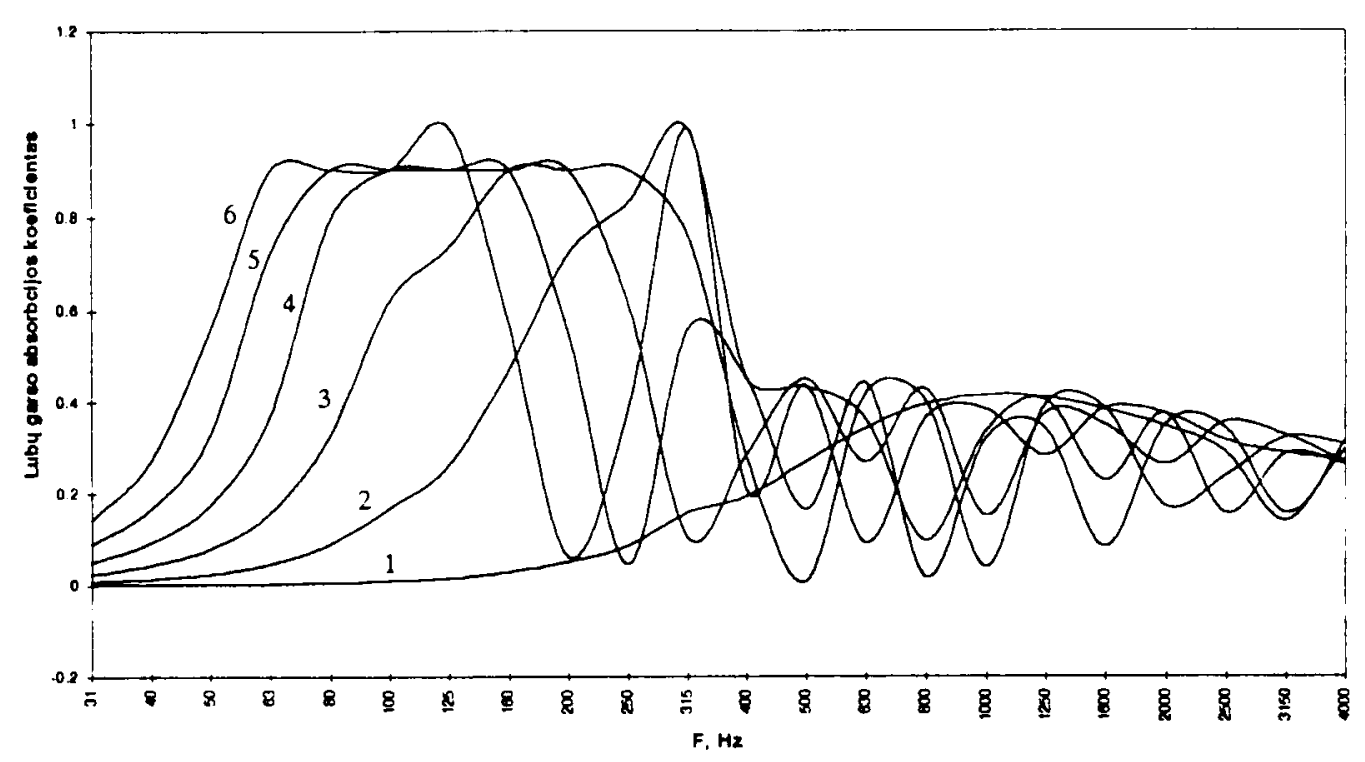

6 pav. Kabamuju lubų su kryžiaus formos plyšiais tarp plokštumy lubų garso absorbcijos koeficientu priklausomybé nuo atstumo tarp plokštumos ir standaus luby paviršiaus. Plyšio plotis $-100 \mathrm{~cm} .1,2,3$, 4,5 is 6 atstumas iki standaus paviršiaus atitinkamai $5,20,35,50,65$ ir $80 \mathrm{~cm}$

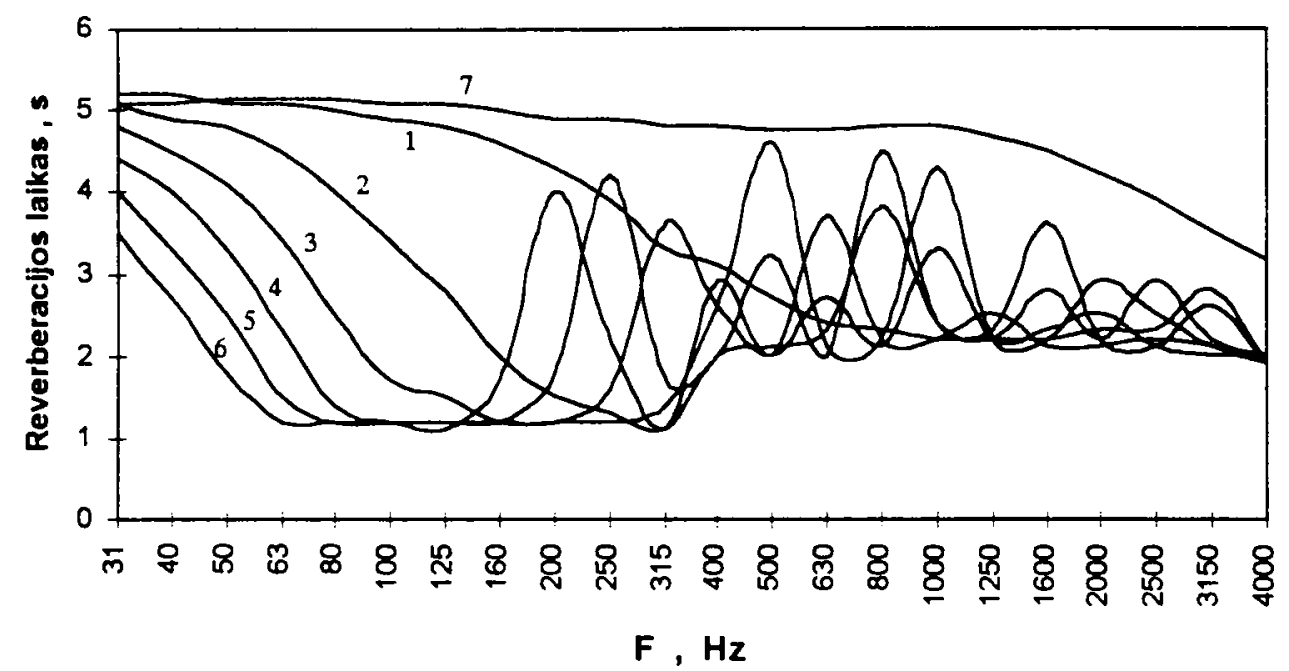

7 pav. Kabamuju lubỵ su kryžiaus formos plyšiais tarp plokštumy visos salès reverberacijos laiko priklausomybe nuo atstumo tarp plokštumos ir standaus lubu paviršiaus. Plyšio plotis $-100 \mathrm{~cm} .1,2,3$, 4,5 ir 6 atstumas iki standaus luby paviršiaus atitinkamai $5,20,35,50,65$ ir $80 \mathrm{~cm}$

Skaičiuojant buvo laikoma, kad lubų plokštumos yra iš standžios medžiagos, kuri gerai atspindi garsą ir blogai jị absorbuoja. Vadinasi pačios lubụ plokštumos garso beveik neabsorbuoja. Taigi, ji absorbuoja tik plyšiai tarp šių plokštumų. Vadinasi, apskaičiuojant absorbcijos koeficientą reikia imti nc visų lubų plotą, bet tik plyšiụ plotą. Tada išeina, kad maksimalus plyšiu garso absorbcijos koeficientas yra ne 0,9 , bet 2,0. Jo kitimo charakteris yra toks pats, kaip ir visų lubų garso absorbcijos koeficiento. Tai galima paaiškinti tuo, kad rezonanso metu padidèja absorbcijos plotas, t.y. rezonatoriaus efektyvumas. Rezonansinès kreivès pločiui ịtakos turi rezonatoriaus tūris.

Garso absorbcijos koeficientą reikia žinoti tam, kad galima būtų apskaičiuoti visos salés reverberacijos laiką. Jo kitimas pavaizduotas 7 paveiksle.

Skaičiavimo rezultatai rodo, kad gaunamas labai didelis reverbercijos laiko sumažejimas esant žemiems 
dažniams. Jis yra net 4 sekundes. Tai lemia didelè garso absorbcija esant šiems dažniams ir maža visos salès garso absorbcija. Reverberacijos laiko kitimui didelę ịtaką daro plokštumos atstumas iki standaus paviršiaus. Kai jis lygus tik $5 \mathrm{~cm}$ (1 kreivè), tai šis laikas esant žemiems dažniams beveik nesumažeja, o esant aukštiems sumažeja net iki 3 sekundžių.

\section{Išvados}

1. Kabamų lubų su kryžiaus formos plyšiais tarp plokštumų garso absorbcija esant pastoviam plyšio pločiui labai prikauso nuo jo atstumo iki standaus lubu paviršiaus. Jam didejjant absorbcijos maksimumas atsiranda vis prie žemesnių dažnių.

2. Didejjant garso bangos kritimo kampui garso absorbcijos maksimumas persistumia aukštų dažnių link.

3. Kabamu lubu su kryžiaus formos plyšiais tarp plokštumu garso absorbcijos koeficientas siekia apie 0,9 ir jo maksimumas yra prie rezonansinio dažnio. Šis dažnis turi tuo mažesnes reikšmes, kuo didesnis kabamuju ų lubų atstumas iki standaus paviršiaus.

\section{Literatūra}

1. F.P. Mechel. About perforated metal sheets on absorbing layers // ACTA ACUSTICA, 1, 1993, p. 175.

2. U. Ingard, R.H. Bolt. Absorption characteristics of acoustic materials with perforated fackings // J. Acoust. Soc. Am., 23, 1991, p. 533.

3. P. Guignouard, M. Meisser, J. F. Allard, P. Rebillard, C. Depollier. Prediction and measurement of the acoustic impedance and absorption coefficient at oblique incidence of porous layers with perforated facings // Noise Control Eng. J., 36, 1991, p. 129.

4. B.Brouard, J.F. Allard, H. Bruneau, W. Lauriks, C. Verhaegen. Acoustical impedance and absobtion coefficient of porous layers covered by a facing of parallel slits // Noise Control Eng. J., 41, 1993, p. 289.

5. E. Skudrzyk. The foundation of acoustics. V. 2. Springer- Verlag. Wien, New York. 1971.

İteikta 19960321

\section{SOUND ABSORPTION CALCULATION IMPEDANCE METHOD FOR RESONATOR CEILING}

\section{Stauskis}

Summary

The theoretical model of the suspended ceiling interspaced between the plane surfaces along and across the hall is analysed. The impedance method is used.

A computer program has been developed to calculate, using the obtained formula, the sound absorption factors of the suspended interairspaced ceiling for the reading hall, the total absorption of this hall and the time of reverberation with varying width of the airspaces and their distance from the stiff plane surface. The obtained calculation results show the significant increase of the total hall absorption for the falling down wavre frequency. For a suitably selected width, number and distance from the stiff plane surface of the airspaces, it is possible to get the same acoustic absorption effect as for the special sound absorbing structures. 